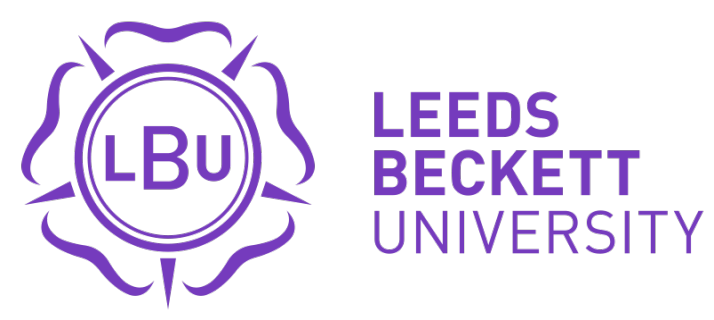

Citation:

Page, D (2017) Conceptualising the surveillance of teachers. British Journal of Sociology of Education, 38 (7). pp. 991-1006. ISSN 1465-3346 DOI: https://doi.org/10.1080/01425692.2016.1218752

Link to Leeds Beckett Repository record:

https://eprints.leedsbeckett.ac.uk/id/eprint/2991/

Document Version:

Article (Accepted Version)

The aim of the Leeds Beckett Repository is to provide open access to our research, as required by funder policies and permitted by publishers and copyright law.

The Leeds Beckett repository holds a wide range of publications, each of which has been checked for copyright and the relevant embargo period has been applied by the Research Services team.

We operate on a standard take-down policy. If you are the author or publisher of an output and you would like it removed from the repository, please contact us and we will investigate on a case-by-case basis.

Each thesis in the repository has been cleared where necessary by the author for third party copyright. If you would like a thesis to be removed from the repository or believe there is an issue with copyright, please contact us on openaccess@leedsbeckett.ac.uk and we will investigate on a case-by-case basis. 


\section{Conceptualising the surveillance of teachers}

\section{Damien Page, Leeds Beckett University \\ Damien.Page@leedsbeckett.ac.uk}

This is an Author's Accepted Manuscript of an article published in British Journal of Sociology of Education (2016), copyright Taylor \& Francis, available online at:

http://www.tandfonline.com/doi/full/10.1080/01425692.2016.1218752 


\title{
Conceptualising the Surveillance of Teachers
}

\begin{abstract}
Schools are risky places: the risk of a poor Ofsted report, the risk of sliding down league tables, the risk of teachers abusing children, the risk of teachers being falsely accused of abuse. As a result of risk anxiety and the ever increasing sophistication of technology, the surveillance of teachers has proliferated, becoming a future-oriented pursuit to manage this risk. Drawing on the surveillance studies literature, this article attempts to theorise the surveillance of teachers. Firstly it argues that there are three types of teacher surveillance: the vertical perpetuated by Ofsted and senior schools leaders such as teaching observations and learning walks, but also students recording their teachers on mobile phones; horizontal surveillance enacted by peers in terms of concertive control but also parental surveillance via online and offline networks; finally, intrapersonal surveillance embracing reflective practice, data reporting and self-policing proximity from children. The article concludes by arguing that while surveillance in schools embraces the themes of modern surveillance in general, by doggedly retaining the proximal and the interpersonal, it should be considered a hybrid form between traditional and modern forms of surveillance.
\end{abstract}

\section{Introduction}

It is almost impossible to write about surveillance without acknowledging Michel Foucault and the panopticon. As a design for a prison created by Jeremy Bentham, the panopticon consisted of a circle of individualised prison cells arranged around a central guard tower with slats at the windows to prevent prisoners from knowing when it was occupied. As such, the discipline of prisoners was to be achieved by the potential for surveillance which, in turn, encouraged prisoners to focus inwards and regulate their own behaviours, disciplining the self and creating 'docile bodies'. For Foucault, panopticism became the central metaphor for surveillance in modern society, a potential gaze that creates self-discipline amongst citizens, workers and the institutionalised. Yet technology and the mass media have engendered such massive changes in surveillance since Foucault that while surveillance theory cannot ignore the panopticon, it can more beyond it, 'accept[ing] the panoptic presence, even if only as the ghost lurking within the post-panoptic world' (Lyon, 2006, p10). While the panoptic has been regularly invoked in educational literature, especially in regards to Ofsted, more recently there is a move towards post-panopticism in understanding surveillance within education contexts (Courtney, 2014; Page, 2015). What is missing so far is a conceptualisation of the surveillance of teachers, one that is founded upon the wider surveillance studies literature (a body of literature that has moved beyond panopticism for some time). This article aims to achieve this synthesis by presenting a model of the surveillance of teachers that operates as three overlapping types: vertical surveillance that includes Ofsted, senior leaders' strategies such as learning walks and surveillance by pupils in terms of student voice and surreptitious video recordings on phones; horizontal surveillance via peer observations, concertive control and parental surveillance via offline and online networks; intrapersonal surveillance, the watching of the self via reflective practice and the self-policing of physical distance from children. The article concludes by further differentiating the surveillance of teachers from panopticism as well as highlighting its difference from contemporary surveillance in general, arguing that teacher surveillance is a hybrid form that retains the interpersonal proximity of traditional forms while simultaneously exploiting the potential of remote and distant surveillance. 


\section{Contemporary surveillance}

While surveillance has always been a feature of institutions and society (Locke, 2010), more recently it has 'emerged as the dominant organizing practice of late modernity' (Lyon, Haggerty and Ball, 2014). In warfare, in the workplace, in the street and online, surveillance has multiplied unceasingly, infiltrating and becoming embedded within almost every aspect of life. At the heart of this proliferation is a preoccupation with risk. A result of political and socioeconomic change since the end of the Second World War (Kroener and Neyland, 2014), the 'risk society' (Beck, 1992) is concerned with the management and prevention of those risks it has itself produced, a concern for the future that produces social and personal anxiety. Yet while a concern with risk may be the antecedent to surveillance, it is technology that has been the mechanism for its spread whether in the miniaturisation of CCTV and drones or in ever more ubiquitous social networks.

Lyon, Haggerty and Ball (2014) identify three major trends in contemporary surveillance. The first trend concerns the process of blurring boundaries. Where once surveillance was primarily the preserve of the state (Rule, 2007), now we are all surveillance workers (Smith, 2014), encouraged to watch others. In some cases this blurring of boundaries is state initiated (Reeves, 2012) such as the 'if you suspect it, report it' campaign in the UK together with a confidential anti-terrorist hotline. Lateral surveillance (ibid) is also a feature of non-criminal contexts, especially in the workplace where open-plan offices allow colleagues to watch each other in an exercise of concertive control (Barker, 1993), the establishment and policing of group norms. Lateral surveillance is also found in our increasing use of social networking as a means to watch the activities of our friends, family and colleagues.

The second trend is that surveillance has become simultaneously more visible and invisible. On the one hand the apparatus of surveillance is ever more observable with CCTV cameras proliferating - in the UK the British Security Industry Authority estimates that there are 5.9 million in the country with 750,000 of these in 'sensitive locations' such as schools, hospitals and care homes (Barrett, 2013). Perhaps exceeding the ubiquity of CCTV are the perpetual demands for personal information, from state interaction such as claiming welfare (Maki, 2011) to social networking and online shopping (Lee and Cook, 2014), each request building vast databases of details on each citizen. On the other hand, Lyon, Haggerty and Ball (2014) also highlight the increasing invisibility surrounding the practices of surveillance with opacity concerning the 'nature and depth of its penetration' (ibid, p3) along with the uses and potential abuses of the data that is collected. Furthermore, there are also the hidden and secretive means of surveillance from the routine such as 'cookies' in internet browsers to hidden video and audio recorders.

The third trend is the 'democratization of surveillance'. Here surveillance is increasingly focused not just on the powerless and the governed but on groups who have historically resisted scrutiny. The mass media and the internet have created the ability for the many to watch the activities of the few - the synopticon in Mathiesen's (1997) terms - whether authorised via press releases or unauthorised via investigative journalism, paparazzi shots or the dissemination of hacked data. Elsewhere we see the employment of mobile phone video-recording technology to record the actions of powerful groups such as the police: we may think of the case of Eric Garner in America who died after being placed in a choke-hold by a police officer, the entire incident 
recorded by a member of the public leading to a massive online campaign and a civil rights investigation (BBC, 2014). We may also think of state-controlled surveillance being used against its own members: in the notorious 'plebgate' case of UK Conservative Chief Whip Andrew Mitchell, CCTV footage from Downing Street was used to present the altercation with police.

What is apparent from even a brief discussion of these trends is that surveillance should be seen as an 'assemblage' (Haggerty and Ericson (2000), a collection of individual technologies and strategies that combine to provide ever more comprehensive means of data collection 'providing for exponential increases in the degree of surveillance capacity' (ibid, p610). Yet the surveillant assemblage is - in strict opposition to Foucault's panopticon - never fixed: never maintaining its shape, it 'morphs and mutates' (Lyon, 2010). But the mutability of surveillance is not restricted to form but to purpose with 'function creep' ever more apparent. Surveillance has therefore become liquid, 'flexible, mobile, seeping and spreading into many areas of life where once it had only marginal sway' (Bauman and Lyon, 2013). Liquid surveillance therefore reflects postmodernity and takes place in cultures 'characterised by fragmentation and uncertainty as many of the once taken-for-granted meanings, symbols and institutions of modern life seemingly dissolve before our eyes' (Staples, 2013, p9). Yet the liquidity of contemporary surveillance concerns not only the forms but the proximity. Where once surveillance relied upon proximity, now it can be achieved at a distance and is, increasingly, automated - facial recognition software in CCTV; the monitoring of workplace emails; computer programmes that look for patterns in key strokes; databases of consumer purchases, all examples of the new, distant, surveillance (Marx, 2007).

Central to the surveillant assemblage is 'social sorting', the 'classifying drive of contemporary surveillance' (Lyon, 2003): the terrorist from the citizen; the criminal from the law-abiding; the credit-worthy from the credit-unworthy; the consumer from the economically inactive.

Categorisation facilitates inclusion and exclusion, ranking, grading leading to differential treatment whether in terms of consumerism or security. But what is sorted is not - ontologically speaking - people but their virtual selves. Haggerty and Ericson (2000) suggest that the surveillant assemblage breaks down the body from its context through abstraction into types of data collected by individual means of surveillance. It is then reassembled through a series of data flows (and databases) to create a 'decorporealized body, a 'data double' of pure virtuality' (ibid, 611) that can be categorised according to whatever paradigms the database interrogators choose.

With categorisation such a key concern, individuals become increasingly afraid of being caught in the wrong category, 'haunted by the spectre of exclusion' (Bauman, 2004, 79). But this is not only fear of being placed in the wrong category by the state; it is also fear of being miscategorised within the consumerist turn, of being positioned as economically inactive or credit unworthy, the 'weeds in the consumerist garden' (Bauman, 2007, p4). In this way, individuals are lured into participation in their own surveillance, willingly completing online credit checks, giving away personal details and even uploading 'selfies' of conspicuous consumption on social networking sites (and let us not forget that social networking sites operate as 'major clearinghouse[s] for serious and systematic surveillance by corporations, crime control agencies, and of course security concerns' (Lyon, 2010, 332)). As such, surveillance can be framed both as 'categorical suspicion' (Marx, 2001) and 'categorical seduction' (Lyon, 1994). Here perhaps, is where contemporary surveillance studies is most removed from Foucault's metaphor - the panopticon, after all, is entirely one-sided and grounded within suspicion. In 
contemporary surveillance, the participation of individuals, lured as they are by consumerist categorisation, is a central feature.

\section{Surveillance in Schools}

Just as risk can be seen as the prime antecedent of the growth of surveillance in general, it can also be seen as the prime motivator for the growth of surveillance in schools in three ways and at three different levels. Firstly, there is the risk to the economy of poorly educated young people. A perpetual feature of politics, stoked by a variety of international comparisons, government after government warns of the damage to the UK's economic competiveness of young people leaving school without a good education, especially in English, maths and science. Secondly there is the institutional level and the risk of poor external accountability measures such as performance in league tables or Ofsted inspections. Here, the concern is driven by the impact upon students but also the impact upon the school in terms of attracting children and the impact upon head teachers' job security, especially when poor inspection results often lead to headteachers 'being disappeared' (Lepkowska, 2014). Thirdly, at the individual level, there is the risk to the child. On the one hand there is the concern to prevent abuse by teachers; on the other hand, a concern of teachers is the risk of being falsely accused of abuse. Here, as in society in general, 'security has morphed into a future-oriented perspective' (Bauman and Lyon, 2013, p5) and so risk-prevention becomes central to the strategy and work of schools and leads to the proliferation and intensification of surveillance - just as surveillance becomes embedded within almost every aspect of social life, so it becomes embedded within almost every aspect of education.

As a result of risk-management, the surveillance of teachers - like surveillance in general - is concerned with sorting and categorisation. In schools, however, rather than sorting the terrorist from the citizen or the credit-worthy from the bankrupt, there are two primary types of sorting. The first type is concerned with sorting the 'good' and 'outstanding' teacher, the categories that pose least risk, from the 'requiring improvement' and 'unsatisfactory' teacher, those who pose most risk to Ofsted and exam results. As such, in common with contemporary surveillance in general, the surveillance of teachers is future-oriented (Bauman and Lyon, 2013): as Ofsted give virtually no notice of inspections, future-orientation becomes perpetual Ofsted readiness, a heightened state of alert should the inspectorate descend (Perryman, 2009; Page, 2013a, Clapham, 2015). The second type is to sort the 'safe' teacher from the 'unsafe' teacher in terms of the safeguarding risk. In a context of heightened anxiety concerning sexual abuse and routine stories in the press of teachers' inappropriate relationships with students, headteachers are reluctant to risk the impact of abuse within their schools and so surveillance becomes a means of monitoring and enforcing 'safe' behaviours and ensuring normalised visibility to prevent the 'problematics of touching' (Piper and Stronach, 2008) and the multiple impacts of teacher misbehaviour.

This article argues that there are three overlapping types of surveillance that watch the work of teachers (see Figure 1). Firstly is vertical surveillance which concerns Ofsted, the schools inspectorate, and the strategies of senior leaders within schools such as CCTV, teaching observations and learning walks. However, vertical surveillance also includes the actions of students who use mobile phones to record teachers. Secondly there is horizontal surveillance which concerns other teachers in terms of peer observation in classrooms but also more routine 
forms such as surveillance in staffrooms. This category also includes parental surveillance which operates directly or through parental networks and collective action (Posey-Maddox, Kimelberg and Cucchiara, 2014). The final category is intrapersonal, self-surveillance that is enacted through reflective practice and self-monitoring. Rather than seeing these categories are distinct, in replicating the liquidity of contemporary surveillance, areas of significant overlap are identified to emphasise the assemblant nature of surveillance within schools. As such, there are no firm boundaries between the three categories reflecting the liquid nature of surveillance (Bauman and Lyon, 2013). For example, surveillance may begin as an intrapersonal act but be exploited by vertical lines of management. The model also highlights how embedded surveillance has become in almost every aspect of teaching and school life. Our everyday social lives are permeated by surveillance, captured on CCTV as we walk along the street, as we buy a $\mathrm{CD}$ on Amazon, as we post a selfie on Facebook. Visibly and invisibly surveillance has become the 'dominant organizing practice of late modernity' (Lyon, Haggerty and Ball, 2014) and this, it can be argued, is as true within schools as within our social lives, expressed within a surveillant assemblage that functions vertically, horizontally and intrapersonally. The rest of this section will discuss each category in turn.

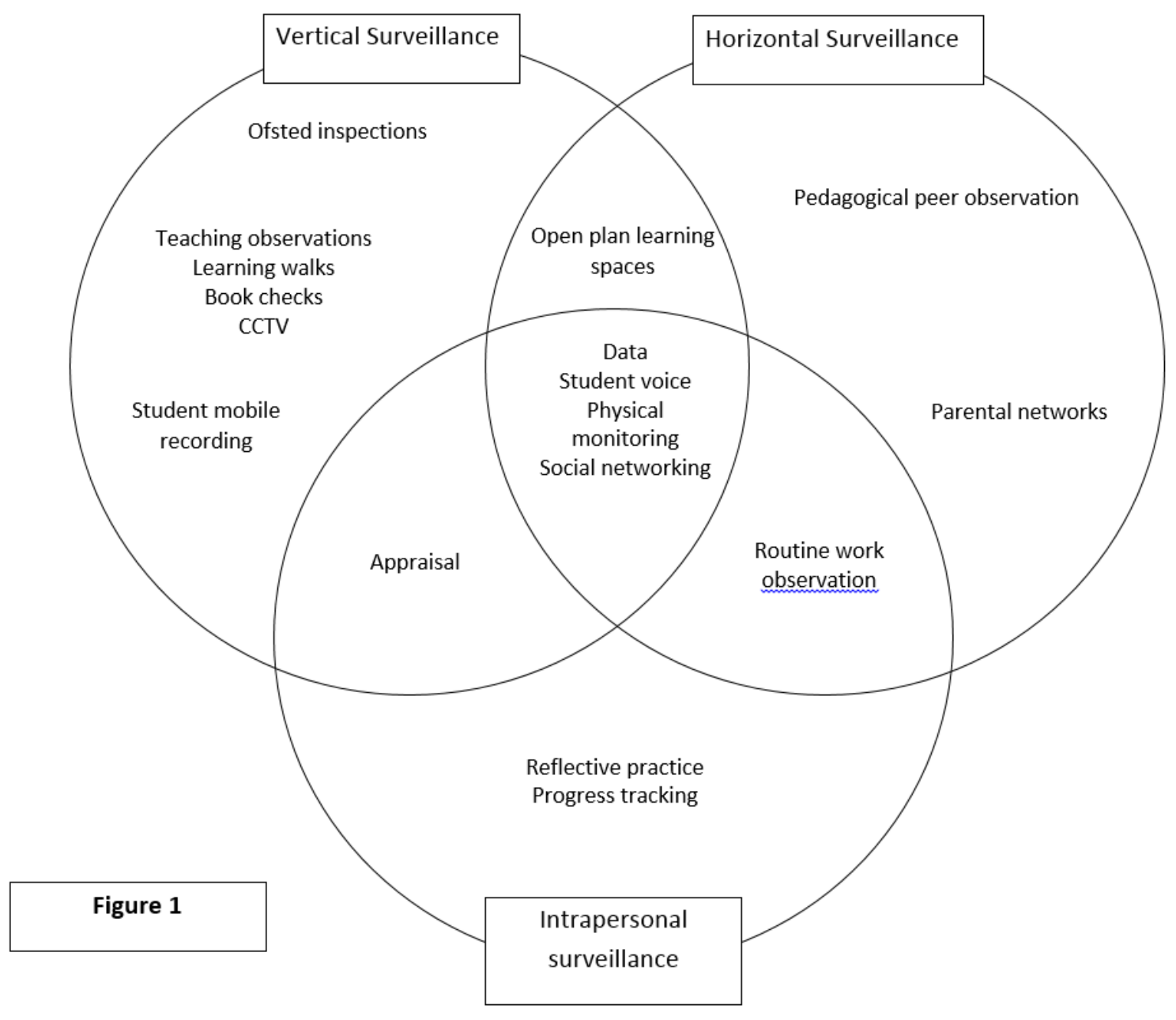




\section{Vertical surveillance}

Vertical surveillance is the archetype in educational studies and looming large in this category is Ofsted. Where once Ofsted inspections were scheduled months in advance with schools given time to prepare, now there is almost no notice of visits, a means of seeing schools 'as they really are'. However, the reduction of notice has meant that schools must now be perpetually Ofstedready, essentially self-surveilling/disciplining in the panoptic sense (Page, 2013a, Chapman, 2015). Yet, as Courtney (2014) argues, where once Ofsted inspections were founded upon inspectors being present in schools, increasingly they (post-panoptically) rely on data, selfevaluation documents and stakeholder perspectives. For the average teacher, an inspection may not mean being observed in classes as it once did as the evaluation of school performance has become more remote from the classroom. With virtually no-notice inspections, the need to be Ofsted-ready falls to headteachers who exert the most significant vertical surveillance within schools. At its most predictable, senior leader vertical surveillance takes the form of teaching observations. Prior to 2010 there was a national agreement that headteachers could not observe teachers for more than three hours per year. New legislation in 2013 (The Education (School Teachers' Appraisal) (England) Regulations 2012), together with a model policy of performance management (DfE, 2012), removed the three hour limit and freed headteachers to observe teachers as often as they liked. However, given that formal observations are usually within specified time periods, the validity of the practice - whether they are a true reflection of routine teaching practice - is limited; with notice of observation, teachers will inevitably prepare showcase lessons in an attempt to maximise their grade. As a result, the use of 'learning walks' has become more prevalent. A typical learning walk consists of a senior leader literally walking around the school and 'popping in' to classrooms whether to stand quietly at the back observing or discussing the lesson with the teacher, talking to pupils and checking their work for progress and the quality of teacher feedback. Such walks are facilitated by the increased use of open plan learning spaces, doorless doorways and glass walls so that senior leaders can quickly spot a cause for concern and investigate. Yet vertical surveillance by senior leaders is not limited to personalised strategies; remote strategies are also increasing. It is estimated that $85 \%$ of schools have CCTV (Taylor, 2014), increasingly in classrooms. While ostensibly CCTV is there to manage risk to students, $55 \%$ of teachers claimed that headteachers viewed the footage, with $41 \%$ suggesting that headteachers used the footage to form negative views of staff (NASUWT, 2014). Furthermore, headteachers are also using structural design to maximise the visibility of staff. For example, schools-within-within schools (Raywid, 1996; Lee and Ready, 2007), an organisational design that uses semi-autonomous small team units enables headteachers to detect the underperformance of individuals far more easily than in large teams (Page, 2015).

However, while top-down forms are the most common type of vertical surveillance, there is also bottom-up surveillance. While mobile phones are usually banned in lessons, a cursory search of a site such as YouTube reveals hundreds of surreptitiously recorded videos of teacher misbehaviour (Page, 2013b), whether more routine forms such as shouting at pupils to extreme misconduct such as violence (see Austin, 2014, for example). The importance of technology to upward surveillance is not just encountered in classrooms of course; despite guidance and institutional policy, examples of teachers engaging with pupils on social networks have appeared regularly in the media, with teachers' posts about drinking, parties and sexual proclivities being reported to headteachers after being viewed by pupils (BBC, 2012). But while technology has 
facilitated student-initiated synopticism, there are also those forms that are initiated by headteachers where top-down and bottom-up vertical surveillance converge. Here is the use of student voice activities, embedded in the 2002 Education Act as a need for schools to consult students. While student voice is sometimes positioned as part of a 'larger emancipatory project' to transform 'oppressive hierarchies' in education (Bragg, 2007), it is also possible to see it in more critical terms as a means of surveillance. Page (2015) found that while headteachers did not explicitly use student voice as a means of identifying poor performance, inevitably children discussed their teachers in terms of efficacy, highlighting cases in need of closer official inspection.

\section{Horizontal surveillance}

While vertical surveillance is embedded within hierarchical power relations, horizontal surveillance primarily concerns peers. With formal teaching observations the preserve of senior leaders within schools, peer observation of teaching is also embedded within the culture of schools. Ammons and Lane (2012) highlight three benefits of peer observation: firstly it provides evidence of internal quality assurance; secondly peer observations may be used by individual teachers as evidence of skill in appraisals or promotion processes; thirdly, it can raise the quality of teaching by disseminating best practice. Of course, especially if peer observation schemes are mandated by senior leaders, such schemes may also be seen as surveillance and can undermine professional autonomy (Singlehurst and Greenhalgh, 2008). Less formally, peer surveillance is also a feature of every staffroom and every open plan office, embedded within the routine work within schools. While power and control are normally seen in vertical terms, here, surveillance and teamwork become intertwined via the emphasis on teamwork as an alternative to hierarchical control. In a team-based approach, workers 'achieve concertive control by reaching a negotiated consensus on how to shape their behaviour according to a set of core values' (Barker, 1993, p411). And if concertive control is the aim, horizontal surveillance becomes the means that polices it: colleagues surveill the punctuality of colleagues; internet use (work or otherwise - see Page, 2014) may be observed by adjacent teachers; conversations are overheard that may concern problems within the classroom. As with vertical surveillance, horizontal forms are also enabled by architecture. Increasingly schools are creating open plan learning spaces that place different classes next to each other without the separation of walls, allowing teachers to not only observe their students but also their peers, especially if a perceived lack of behaviour management by their colleague impedes the learning of their own class.

Horizontal surveillance also captures the activities of parents in monitoring the activities and effectiveness of teachers (Crozier, 1998). Operating within networks (Hassrick and Schneider, 2009), parents surveill the work of teachers via a variety of means: from direct observation of teaching to ad hoc observations in corridors and offices during visits, from children's narratives to direct communication with teachers, data is shared throughout the network to guide parental interaction and intervention. According to Hassrick and Schneider, parental surveillance seeks to determine the activities and efficacy of teaching, 'enhancing their ability to 'customize' the educational experiences of their child through homebased interventions' (ibid, p196). Yet however well intentioned, parental surveillance can also undermine teachers and erode trust relations. While traditional parental networks are founded upon interpersonal relationships and proximal observation, technology now provides a direct means of surveillance for parents: an 'app' such as Homeroom (https://gethomeroom.com) allows parents to view classroom activities 
and their child's work: a teacher may film a child's presentation to the class, upload it to the parent's private album so that it may be viewed remotely. Parents may then choose to share the album with other parents and create discussion boards around the video, gathering additional and comparative information through the virtual parental network and notification when other parents make public their child's learning, applying the functions of Facebook to the classroom. Such apps offer the potential for the parental network to surveill the work of teachers more thoroughly and more remotely than ever before, facilitated by the teacher themselves.

\section{Intrapersonal surveillance}

Intrapersonal surveillance begins with the highly panoptic and involves the internalisation of disciplinary surveillance. Perhaps the most common form of intrapersonal surveillance is reflective practice (see for example Baszile, 2008), ubiquitous within teacher training and continuing professional development as well as being enshrined within notions of teacher professionalism. Often positioned as 'transparently an intrinsically worthwhile activity' (Bleakly, 1999, p320), it may more critically be viewed as a form of intrapersonal surveillance as part of a 'managerialist orthodoxy' (Clegg, 1999). From reflecting upon their own teaching after a teaching observation to reflecting on their feedback practices during an appraisal, reflective practice provides insights not available to senior leaders by other means. However, intrapersonal surveillance is not only reflective - schools rely on Management Information Systems (MIS) to monitor real-time performance of pupils and, by implication, teachers. With these systems, teachers routinely enter data to track pupil progress for collation and analysis by senior managers and other interested parties such as Ofsted, allowing the targeting of issues as they emerge rather than at the stage of exam results. School Information Management Systems (for example, http://www.capita-sims.co.uk/our-products) allow teachers to enter data concerning attendance, behaviour and progress of their students facilitating the identification of underperformance in groups; it also facilitates the identification of the underperformance of individual teachers far more precisely and systematically. Here, we clearly see the liquid nature of surveillance from an intrapersonal act to the exploitation of that data by senior leaders.

Intrapersonal surveillance is also found embedded within the risk culture within schools. With perceptions of declining trust in the profession (a theme of contemporary modernity according to Giddens (1991)), teachers' sense of risk is exacerbated, a heightened 'risk consciousness' in Sachs' (2004) terms. With a relentless stream of stories concerning abuse in the media, the touching of children by professionals has become an area where 'fear, confusion, contradictions and moral panic threaten a more measured response' (Piper and Smith, 2003, p879). Such anxiety leads teachers to rigorously enforce physical distance between themselves and children to avoid potential accusations of being an educational 'predator' (Shakeshaft, 2013), checking that they maintain an appropriate distance at all times and avoiding touch. Not only do riskaverse teachers self-surveill, they may also make themselves visible at all times as a 'sensible, central strategy for ensuring that children are safe from adult sexual abuse and that teachers are safe from accusations of abuse' (Jones, 2004, p54). In such an environment, it is not enough to not touch children; teachers must be seen to not touch children which closely connects horizontal and intrapersonal forms. As such, intrapersonal surveillance may impel teachers to use the architecture of their schools to their advantage in this regard, exploiting the normalised visibility created by CCTV, doorless doors, open plan learning spaces and glass walls. 


\section{Compound surveillance}

While we may examine the surveillance of teachers in terms of vertical, horizontal and intrapersonal, what is clear from this model are the areas of overlap that highlight the sites of compound surveillance involving multiple levels and multiple parties. In some cases compound surveillance is intimate, dyadic in the case of appraisals with its shades of the confessional (Barry, Chandler and Clark, 2001). Here the intrapersonal surveillance of reflective practice and data entry of pupil progress become conjoined with senior management evaluations derived from teaching observations, learning walks and data analysis. Elsewhere the increasingly open plan architecture of schools allows for senior leaders, peers, pupils and visiting parents to view the activities of teachers in situ, not only in terms of teaching and learning strategies but also the physical proximity of teachers to their students. In offices and staffrooms as well as in social networks, during the exercise of concertive control, peer watching combines with self-watching to regulate institutional and cultural norms. Student voice activities work to evidence practice for all: headteachers may solicit feedback from students as part of improvement; students may complain about individual teachers to that teacher's peers; children will tell their parents about their day; teachers may ask for student evaluations of their teaching efficacy. Equally as diverse is the role of data in the surveillance of teachers with each stakeholder able to create, interrogate and report data in a process of atomisation that informs on the performance of student, teacher, team, department and school.

\section{Beyond the panoptic school}

In traditional conceptions, surveillance is something that was done to subordinates by senior leaders. Surveillance was an exercise of hierarchical power, a strategy of data collection to inform performance management, a means of weeding out the bad apples before Ofsted visited. Surveillance in schools, then, has always been a product of risk anxiety, a future oriented pursuit to prevent poor outcomes and negative consequences. To that extent, little has changed. What has changed is the intensity of risk that is experienced by headteachers and the resulting stress (Phillips and Sen, 2011). Where once an Ofsted grade of 'satisfactory' was satisfactory, now there is 'requiring improvement' that may lead to the disappearing of headteachers and forced academisation as punishment for 'coasting' (Chapman, 2015). With ever increasing risk anxiety comes the intensification and proliferation of downwards surveillance: learning walks, book checks, data analysis, student voice, appraisal, small-team organisation, open plan learning, glass walled classrooms, CCTV, social networking - the tools for headteachers to surveill their staff have multiplied. Here we see the first of the trends of contemporary surveillance identified by Lyon, Haggerty and Ball (2014) enacted within schools, the blurring of boundaries: while formal teaching observations sit within official surveillance and performance management, the status of learning walks, pupil feedback and social networking remain contested and the boundaries between official and unofficial surveillance become blurred.

This model highlights other changes to the surveillance of teachers that also moves beyond the downwards gaze of the panoptic. Firstly, there is the advent of upwards surveillance by students. While education is founded upon the students watching the teacher, the ubiquity of mobile technology has transformed the watching into surveillance. Students have always shared tales about their teachers amongst themselves or to headteachers and parents; now, however, recordings of teachers can be edited and uploaded to the internet for scrutiny within seconds. Students are also skilled at searching the internet for details about their teachers such as a 
clumsily expressed Tweet or an inappropriately posed picture on Facebook. While these forms of surveillance are usually officially prohibited, headteachers simultaneously encourage students' surveillance of their teachers framed as 'student voice', a strategy of data collection of teacher performance couched within notions of student empowerment. Mirroring the rise of student surveillance is the intensification of parental forms of surveillance with technology enhancing the traditional interpersonal networks, with data shared between online and offline social networks, evaluations shared online on sites like Parent View (https://parentview.ofsted.gov.uk), child progress monitored via book checks, online progress reports and apps. Here, again, risk anxiety is the antecedent, especially among middle class parents (Hassrick and Schneider, 2009) and again surveillance is future oriented: their child's test results at primary that affect their choice of secondary school that affects their choice of university that affects their choice of career that affects their social and financial standing - all inculcations of neo-liberal discourses of choice, marketisation and competition. Here is the third of Lyon, Haggerty and Ball's (2014) trends, the democratisation of surveillance, synopticonism. Here surveillance is employed by those who have no hierarchical or formal power over teachers yet, by engaging in surveillance, a different form of power is enacted, a power that is coercive.

Both of these features - blurring of boundaries and democratisation - move the surveillance of teachers beyond the panoptic. The notion of intrapersonal surveillance, however, is perhaps the form and practice that most defines the surveillance of teachers as distinct from panopticism. The watching of the self does begin, however, with panopticism: with the potential for being seen as any time, Foucault (1991) argues that the gaze moves inside, discipline becomes internalised to produce 'docile bodies'. What panopticism cannot account for in contemporary surveillance is the active, agentive and willing participation within practices of surveillance. For Bauman and Lyon (2013), the primacy of social society - the primary purpose of surveillance - has moved the prospect of being watched from a menace to a temptation: the "promise of enhanced visibility, the prospect of 'being in the open' for everybody to see and everybody to notice, chimes well with the most avidly sought proof of social recognition, and therefore of valued 'meaningful' - existence' (p23). Within the consumerist turn, individuals recreate themselves as commodities to create a demand for themselves and to attract rewards. This recreation is - in Bauman and Lyon's terms - a 'DIY job' engendered by the fear of being cast within the category of undesirable. If surveillance is primarily a task of sorting and categorisation, individuals actively and willingly participate within and enact their own surveillance to ensure they are categorised within the good categories rather than the bad. We may think of the modern preoccupation with networking oneself as a brand, posting our achievements on our LinkedIn profile, uploading 'selfies' from exotic holiday destinations on Instagram, emphasising our displays of conspicuous wealth on Facebook. Teachers are arguably no different. If surveillance in schools functions to separate the good-and-outstanding from the inadequate-and-requiringimprovement, teachers are naturally concerned to ensure their identification in the right category; their reputation, their perception of their self-efficacy and their continued employment depend upon it after all. As such, in contexts where visibility has become normalised (Page, 2015), teachers are offered an opportunity to use surveillance as a means to sell themselves as commodities, to show off their teaching prowess, to highlight best-practice, to display their internalisation of school strategy. During teaching observations they may present their very best practice, every trick in the pedagogical box. In appraisals they may present case studies of their skill that turned a failing student into a grade A student. In the data they upload tracking class 
performance, parameters may be manipulated to increase the extent of 'distance travelled' by their students. Innovative media-rich resources may be conspicuously shared among whole departments. And the rewards, the temptation of the consumerist turn embedded within schools? To be categorised as good-or-better, to be awarded performance related pay, to be promoted.

\section{Hybridity}

In many ways, the surveillance of teachers exemplifies the general trends and strategies of contemporary surveillance: it is promulgated by risk and facilitated by technology; it is futureoriented; it is liquid and involves function creep, blurring traditional boundaries; it is increasingly democratised. Yet there is one major feature of contemporary surveillance to which the school context does not conform, that of proximity. In current surveillance studies, the principle that surveillance is becoming more distant has become a truism (see for example Marx, 2007; Lyon, 2010; Bauman and Lyon, 2013). Whether via CCTV, drones or databases, the mechanisms of surveillance are increasingly removed from the individual, operating at a distance. Remote surveillance is also increasingly automated whether in terms of facial recognition software or statistical surveillance programmes (Gandy, 2014) that analyse electronic transcriptions of speech. To an extent, surveillance in schools has become more distant. Data is removed from teachers, CCTV operates remotely, social network monitoring is virtual. There is also an increase in automated surveillance to monitor students within schools (Hope, 2015, Taylor, 2014). However, while remote surveillance of teachers may be intensifying, so is the proximal surveillance of teachers: teaching observations have become more frequent by statute as well as practice, learning walks are often conducted every lesson, teachers teach next to their peers in open plan learning spaces and glass classrooms, parents are increasingly encouraged to participate in school activities. As such, the surveillance of teachers has become more proximal and more interpersonal, not less. Teacher surveillance then, rather than being located within either the traditional or contemporary paradigms of surveillance, may be viewed as a hybrid of the two.

Why then has the surveillance of teachers resisted remoteness and distance? There are two main binary possibilities. Firstly, it may be argued that senior school leaders recognise that teaching and learning is a process too complex to be reducible to statistics and distant interpretations. At a time when governments, Ofsted and newspaper league table compilers continually offer evidence that teaching is reducible to statistical outputs, the proximal surveillance of teachers counters with evidence that teaching and learning must be experienced rather than reduced; real judgements of quality may only be formed by being in a classroom, experiencing the atmosphere and the climate, the presence and style of the teacher and the mood of students. A grade $\mathrm{C}$ is a grade $\mathrm{C}$ statistically but senior leaders may recognise that this takes no account of the possible stories behind it, the quality of relationship between teacher and student, the determination of both, the quality of the learning environment, all factors that may have transformed an $\mathrm{E}$ grade into that $\mathrm{C}$ grade. From this perspective, senior school leaders may be seen as preserving the richness of teaching and resisting the reductionism of remote surveillance. From this perspective, the proximal surveillance of teachers - in all of its forms - is a means of respecting the art and richness of teaching and the professionalism of teachers by maintaining face to face measures of accountability, keeping surveillance visible and personal. 
Alternatively, in binary opposition, the retention of proximal teacher surveillance may signal a lack of trust not only in teachers but in the means of remote surveillance. As Giddens (1991) reminds us, the "prime condition of requirements for trust is not lack of power but lack of full information' (p33) and so a hybrid model of surveillance where senior leaders attempt to make the work of teachers fully and continually visible renders trust obsolete. Like the first possibility, this perspective recognises the richness and complexity of teaching, a richness and complexity that cannot be reduced to statistical analysis. However, here proximal surveillance may be retained as a means of ensuring teachers cannot resist more distant and automated surveillance. While surveillance - both panoptic and post-panoptic - is often presented in terms of Orwellian indomitability, the vast literature on workplace resistance suggests that workers will always find space within the 'cracks and crevices of inter-subjective relations and other quiet subterranean realms of organizational life' (Fleming and Sewell, 2002, p863): CCTV has blind spots; data may be fiddled to show inflated performance or lower starting points; student voice may be manipulated through strategies of ingratiation and persuasion; impression management may present a more effective picture at appraisals. If teaching is a rich and complex practice, it may offer plentiful terrain for hidden resistance, resistance that may only be found up close and personal. In a demonstration of distrust of both teachers and remote surveillance, senior school leaders may pursue the proximal as a means of detecting resistance, of sniffing out the bad apples that may resist detection by other means. From this perspective, the risk anxiety of senior school leaders may have been heightened to such an extent that they experience organisational paranoia, a heightened sense of self-consciousness resulting from intense 'evaluative social scrutiny' (Kramer, 1998), arguably the default position for headteachers. After all, with schools more visible that ever, it is not just the teachers who are being surveilled and whose wellbeing and continued employment rest on sorting and categorisation: internally the primary role of the governing body is to surveill and evaluate the headteacher's performance. Just as with teachers, this includes the vertical in terms of data analysis but also the intrapersonal during the appraisal/performance review undertaken by governors. And, even more than for teachers, Ofsted inspections are judgements on the senior leadership. In this respect, the school as transparent functions not only to reveal but to exhibit the spectacle of good-and-outstanding leadership.

\section{The problem of contemporary surveillance studies}

The perspective of contemporary surveillance studies (and this article) that liquid surveillance has seeped into every aspect of life and work of course risks rendering surveillance as a concept oblique and, from that perspective, analytically problematic: if surveillance is everything and everywhere, how can we understand it? The key is to understand that the liquidity of surveillance is a product of the 'fluid and unsettling modernity of today' (Bauman and Lyon, 2013, p2-3):

all social forms melt faster than new ones can be cast... surveillance, once seemingly solid and fixed, has become much more flexible and mobile, seeping and spreading into many life areas where once it had only marginal sway (ibid, p3).

The conceptualisation of surveillance in previous decades was undoubtedly more solid, capturing the nature of fixed CCTV cameras and fixed Ofsted inspections, surveillance as a product of easily determinable hierarchical power. In the 'modernity of today', traditional conceptualisation and analytical certainty cannot adequately capture contemporary surveillance, 
it has become too embedded within daily life and daily work, too normalised in the experiences of individuals. As such, this paper - in common with surveillance studies - does not argue that everything is surveillance. Rather, it argues that surveillance has become deeply embedded within the routine practices of schools and that embeddedness has become the central concept for contemporary surveillance, the central principle of analysis. The task of surveillance studies therefore becomes to work with conceptual uncertainty and to accept that surveillance is difficult to extricate from its social context. The task (and the purpose of this article) is to map its liquidity, to highlight function creep (Ball, 2010), to conceptualise the assemblage (Haggerty and Ericson, 2000) that exists in contexts such as schools, however indistinct and resistant it may be to secure boundaries: our analytical metaphor should be a bucket rather than a net, considering the individual methods of surveillance within their liquid context, however problematic this may be conceptually or analytically. Only by this approach can we concern ourselves with the very real impacts of surveillance which should be our aim.

\section{Conclusion}

While teaching is an inherently risky profession (Hardy, 2015), the risk anxiety within schools has proliferated exponentially. Whether in the risk of a poor Ofsted inspection or the risk of child abuse, risk has become central to the management of the contemporary school and is the prime antecedent of the massive increase in the surveillance of teachers. A future-oriented pursuit, surveillance in schools - like surveillance in general - seeks to sort and categorise teachers, sorting the unsatisfactory from the outstanding, the organisational citizen from the organisational deviant, the safe teacher from the predator. Facilitated by developments in technology, the surveillance of teachers operates at three levels: vertical surveillance by Ofsted, senior leaders and students, horizontal surveillance by peers and parents and intrapersonal surveillance by the self. Yet rather than seeing each type as distinct, this article identifies those areas of compound surveillance where the types come together in a true assemblage. What is clear is that the surveillance of teachers has moved beyond the panoptic, beyond the fixed walls and potential - it has become liquid, fluid, blurring boundaries, becoming democratised and seductive, luring the surveilled to become willingly complicit in their own surveillance. Yet while the surveillance of teachers has embraced the general trends of distance, remoteness and automation, there is a dogged clinging on to the interpersonal and the proximal that marks schools apart from other contexts. Despite the opportunities offered by technology, teachers are still surveilled at close range, watched formally and informally, hierarchically and non-hierarchically by headteachers, peers, students and parents. As such, the surveillance of teachers is a hybrid model, a blend of the new forms of surveillance and the old interpersonal forms: whether motivated by senior leader trust or distrust, up close and personal is not leaving teacher surveillance.

Yet while this article has focused on teachers, the model proposed could equally be form the basis of conceptualising the surveillance of other public-facing professions such as nursing, social work and policing, each of which is situated within a context of risk and problematic trust. Workers in each of these areas face vertical, horizontal and intrapersonal methods of surveillance, from patient feedback forms at routine appointments to police officers wearing body cameras, from perpetual scrutiny of CPD activities to the observations of the general public. Just as surveillance has become the organising primary organising principle of modern social life, so it may have become the defining principle of professional work. 


\section{References}

Ammons, J. L., and Lane, S. J. 2012. "Making teaching visible: sharing and evaluating using peer observation". Academy of Educational Leadership 17 (1): 77-92

Austin, H. 2014. "Horrifying moment a Polish music teacher began STRANGLING an epileptic boy of 12 in an effort to keep him quiet". Mail Online. Accessed January 262015 http://www.dailymail.co.uk/news/article-2869895/Horrifying-moment-Polish-musicteacher-began-STRANGLING-epileptic-boy-12-effort-quiet.html

Barker, J. R. 1993. "Tightening the iron cage: concertive control in self-managing teams". Administrative Science Quarterly 38 (3): 408-437

Barrett, D. 2013. "One surveillance camera for every 11 people in Britain, says CCTV survey". The Telegraph. Accessed February 22015 http://www.telegraph.co.uk/technology/10172298/One-surveillance-camera-for-every11-people-in-Britain-says-CCTV-survey.html

Barry, J., Chandler, J. and Clark, H. 2001. "Between the ivory tower and the academic assembly line". Journal of Management Studies 38 (1): 87-101

Baszile, D. T. 2008. "The oppressor within: A counterstory of race, repression, and teacher Reflection". The Urban Review 40 (4): 371-385.

Bauman, Z. and Lyon, D. 2013. Liquid Surveillance. Cambridge: Polity Press

Bauman, Z. 2004. Europe. Cambridge: Polity Press

Bauman, Zygmunt. 2007. Consuming Life. Cambridge: Polity Press

BBC. 2012. "Facebook drinking posts teacher Elizabeth Scarlett reprimanded". BBC News. Accessed February 2 2015. http://www.bbc.co.uk/news/uk-wales-south-east-wales16929442

BBC. 2014. "Eric Garner death: US orders civil rights inquiry". BBC News. Accessed December 122014 http://www.bbc.co.uk/news/world-us-canada-30323750

Beck, U. 1992. Risk society: Towards a new modernity (Vol. 17). New York: Sage

Bogard, W. 2007. "Surveillance, its simulation and hypercontrol in virtual systems". In Ball, K., Haggerty, K. and Lyon, D (Eds) Routledge Handbook of Surveillance Studies, p30-37, Routledge, Oxon

Bragg, S. 2007. "Student voice and governmentality: the production of enterprising subjects?" Discourse: studies in the cultural politics of education 28(3): 343-358.

Chapman, J. 2015. "Up to 3,500 coasting schools could be taken over in Cameron's 'all out war on mediocrity"'. Mail Online. Accessed Feburary 52015 http://www.dailymail.co.uk/news/article-2935690/3-500-coasting-schools-turnedacademies-war-mediocrity-David-Cameron-remains-power.html

Clapham, A. 2015. "Post-fabrication and putting on a show: examining the impact of short notice inspections". British Educational Research Journal 41 (4): 613-628

Clegg, S. 1999. "Professional education, reflective practice and feminism". International Journal of Inclusive Education 3(2): 167-179.

Courtney, S. J. 2014. "Post-panopticism and school inspection in England". British Journal of Sociology of Education. DOI:10.1080/01425692.2014.965806

Crozier, G. (1999). Parental involvement: who wants it?. International Studies in Sociology of Education, 9(3), 219-238.

DfE. 2012. "Teacher appraisal and capability: a model policy for schools". Accessed January 21 
2015

https://media.education.gov.uk/assets/files/pdf/m/model\%20policy\%20rev\%2017\%20ma y\%20branded.pdf

Fleming, P. and Sewell, G. 2002. "Looking for the good soldier, Svejk: alternative modalities of resistance in the contemporary workplace". Sociology 36(4): 857-873

Foucault, M. 1991. Discipline and punish - the birth of the prison. London: Penguin

Gandy, O. 2014. "Statistical surveillance: remote sensing in the digital age". In Routledge Handbook of Surveillance Studies, edited by Kirstie Ball, Kevin Haggerty and David Lyon, 125-132. Routledge: Oxon

Giddens, A. 1991. The consequences of modernity. Polity: Cambridge

Haggerty, K and Ericson, R. 2000. "The surveillant assemblage". British Journal of Sociology 51 (4): 605-622

Hardy, I. 2015. "Education as a 'risky business': Theorising student and teacher learning in complex times". British Journal of Sociology of Education 36 (3): 375-394

Hope, A. 2015. "Biopower and school surveillance technologies 2.0". British Journal of Sociology of Education. DOI: 10.1080/01425692.2014.1001060

Kramer, R. M. 1998. "Paranoid cognition in social systems: thinking and acting in the shadow of doubt". Personality and Social Psychology Review 2 (4): 251-275

Kroener, I. and Neyland, D. 2014. "New technologies, security and surveillance". In Routledge Handbook of Surveillance Studies, edited by Kirstie Ball, Kevin Haggerty and David Lyon, 141-148. Routledge: Oxon

Lee, A., and Cook, P. S. 2014. "The conditions of exposure and immediacy: Internet surveillance and Generation Y". Journal of Sociology. DOI:1440783314522870.14/01/15)

Lee, V. and Ready, D. 2007. Schools within schools: possibilities and pitfalls of high school reform. New York: Teachers College Press

Lepowska, D. 2014. "A poor Ofsted report could lead to headteachers being 'disappeared"'. The Guardian. Accessed January 212015 http://www.theguardian.com/education/2014/mar/11/heads-poor-ofsted-report-dismissalshortages

Locke, J. L. 2010. Eavesdropping: An Intimate History. Oxford: Oxford University Press

Lyon, David. 1994. The Electronic Eye: The Rise of the Surveillance Society. Cambridge: Polity Press

Lyon, D. 2003. "Surveillance as social sorting”. In Surveillance as Social Sorting:

Privacy, Risk and Digital Discrimination, edited by David Lyon, 13-30. London:

Routledge

Lyon, D. 2006 "The search for surveillance theories". In Theorizing surveillance, edited by

David Lyon, 3-20. London: Routledge

Lyon, D. 2010. "Liquid Surveillance: The Contribution of Zygmunt Bauman to Surveillance

Studies". International Political Sociology 4 (4): 325-338

Lyon, D., Haggerty, K. and Ball, K. (2014) "Introducing surveillance studies". In Routledge Handbook of Surveillance Studies, edited by Kirstie Ball, Kevin Haggerty and David Lyon, 1-12. Routledge: Oxon

Maki, K. 2011. "Neoliberal Deviants and Surveillance: Welfare Recipients under the watchful eye of Ontario Works. Surveillance and Society 9 (1/2): 47-63

Marx, G. T. 2001. "Murky conceptual waters: The public and the private". Ethics and 
Information Technology 3(3): 157-169.

Mathiesen, T. 1997. "The viewer society: Michel Foucault's panopticon revisited". Theoretical Criminology 1 (2): 215-234

NASUWT. 2014. "Monitoring of teachers-a shocking catalogue of professional disrespect and unacceptable intrusion". Accessed January 172015 http://www.nasuwt.org.uk/Whatsnew/NASUWTNews/PressReleases/CCTVMonitoringO fTeachersSurvey

Page, D. 2013a. "The abolition of the General Teaching Council for England and the future of teacher discipline". Journal of Education Policy 28(2): 231-246

Page, D. 2013b "Teacher misbehaviour: an analysis of disciplinary orders by the General Teaching Council for England". British Educational Research Journal 39 (3): 545564

Page, D. 2014. "Teachers' personal web use at work". Behaviour and Information Technology DOI:10.1080/0144929X.2014.928744

Page, D. 2015 "The visibility and invisibility of performance management in schools". British Educational Research Journal, Online First: DOI: 10.1002/berj.3185

Perryman, J. 2009. "Inspection and the fabrication of professional and performative Processes". Journal of Education Policy 24 (5): 611-31

Phillips, S., and Sen, D. 2011. "Stress in head teachers". In Handbook of Stress in the Occupations, edited by Janice Langan-Fox and Cary Cooper, 177-200. Gloucestershire: Edward Elgar

Piper, H., and Smith, H. 2003. “'Touch' in educational and child care settings: dilemmas and Responses". British Educational Research Journal 29(6): 879-894

Piper, H., and Stronach, I. 2008. Don't Touch!: The Educational Story of a Panic. London: Routledge

Posey-Maddox, L., Kimelberg, S. and Cucchiara, M. 2014. "Seeking a 'critical mass': middleclass parents' collective engagement in city public schooling". British Journal of Sociology of Education, DOI: 10.1080/01425692.2014.986564

Reeves, J. 2012. "If you see something, say something: lateral surveillance and the uses of Responsibility". Surveillance and Society 10 (3/4): 235-248

Rule, J. 2007. Social control and modern social structure. In The Surveillance Studies Reader, edited by Sean Hier and Josh Greenberg, 19-27. Berkshire: Open University Press

Shakeshaft, C. 2013. "Know the warning signs of educator sexual misconduct". Phi Delta Kappan 94(5): 8-13

Singlehurst, D., Russell, J., and Greenhalgh, T. 2008. Peer observation of teaching in the online environment: an action research approach. Journal of Computer Assisted Learning 24(5): 383-393.

Smith, G.J.D. 2014. Surveillance work(ers). In Routledge Handbook of Surveillance Studies, edited by Kirstie Ball, Kevin Haggerty and David Lyon Routledge: Oxon

Staples, G. 2013. Everyday Surveillance: Vigilance and Visibility in Postmodern Life, Second Edition. Plymouth: Rowman and Littlefield

Taylor, E. 2014. "The rise of the surveillance school". In Routledge Handbook of Surveillance Studies, edited by Ball, K., Haggerty, K. and Lyon, D. Routledge: Oxon 
